\section{Plasma pharmacokinetics, tissue concentrations and urine elimination after cephalothin intravenous administration to cats under surgical conditions}

\author{
Gabriela A. Albarellos, 1 Laura Montoya, 1 \\ Martín P. Lupi,1 Sabrina M. Passini,1 \\ Paula Lorenzini, 1 María Fabiana Landoni² \\ 1Department of Pharmacology, Faculty of \\ Veterinary Sciences, University of Buenos \\ Aires; 2Department of Pharmacology, \\ Faculty of Veterinary Sciences, National \\ University of La Plata, Buenos Aires, \\ Argentina
}

\section{Abstract}

Pharmacokinetic profile, tissue concentrations and urine elimination of cephalothin in cats under surgical conditions after a single intravenous dose $(30 \mathrm{mg} / \mathrm{kg})$ were studied. Initial plasma concentrations were high $\left[\mathrm{C}_{\mathrm{p}(0)}\right.$, $353.79 \pm 118.92 \mu \mathrm{g} / \mathrm{mL}$, with fast and moderately wide distribution [ $\mathrm{T}_{1 / 2(\mathrm{~d})} \quad 0.14 \pm 0.10 \mathrm{~h}$ ] $\left[\mathrm{V}_{(\mathrm{d}(\mathrm{ss}))} 0.19 \pm 0.03 \mathrm{~L} / \mathrm{kg}\right]$ and rapid elimination $\left(\mathrm{Cl}_{\mathrm{B}}, 0.16 \pm 0.03 \mathrm{~L} / \mathrm{h} . \mathrm{kg} ; \mathrm{T}_{1 / 2}, 1.07 \pm 0.23 \mathrm{~h}\right.$; MRT, $1.16 \pm 0.21 \mathrm{~h})$. Thirty to 60 minutes after intravenous administration, cephalothin tissue concentrations were in the range of $3.73 \mu \mathrm{g} / \mathrm{g}$ (testicle tissue) to $25.63 \mu \mathrm{g} / \mathrm{g}$ (uterus). Tissue/plasma concentrations rate was in a range of 0.04 (testicle) to 0.21 (uterus). Cephalothin urine elimination was $66.49 \%$ in the first 6 hours after administration. Cephalothin plasma concentrations remained above a minimum inhibitory concentration (MIC) $\geq 1 \mu \mathrm{g} / \mathrm{mL}$ up to 5.5 hours in all the studied cats. However, for $\mathrm{MIC} \geq 8 \mu \mathrm{g} / \mathrm{mL}$ (MIC breakpoint) this time is reduced to 2.5 hours. This suggests that proper perioperative prophylactic use of cephalothin in cats requires a dose interval not longer than 2 hours.

\section{Introduction}

Cephalothin, along with cefazolin, is a member of the parenteral first-generation cephalosporins. It is active against many grampositive cocci, like Staphylococcus spp., including beta-lactamase producing strains, and Streptococcus spp (except Enterococcus). It is also active against some gram-negative rods like those of the Enterobacteriaceae family ( $E$. coli, Klebsiella, Proteus mirabilis) and Pasteurella spp; and, it has some activity against anaerobes.1,2 Minimum inhibitory concentration (MIC) breakpoint for bacteria isolated from animals has been set in $\leq 8 \mu \mathrm{g} / \mathrm{mL}^{3}$ Beta-lactams are classified as Type II antimicrobials which are characterized for a timedependent killing and minimal persistent effects. The time they remain above the MIC (T>MIC) is the PK/PD efficacy predictor that best correlates with successful antibacterial therapy. For cephalosporins, a T>MIC of $50 \%$ of the dosing interval is considered suitable for most gram-positive bacteria. However, for gram-negative infections, bactericidal activity is optimal with $\mathrm{T}>\mathrm{MIC}$ of $60-70 \%$ of the dosing interval. ${ }^{1}$ While, for neutropenic patients a T>MIC of $90-100 \%$ is recommended. 4

Cephalothin pharmacokinetics has been studied in laboratory animals, ${ }^{5-7} \mathrm{dogs},{ }^{7-10}$ and horses. ${ }^{11}$ However, to the authors' knowledge it has not been studied in domestic cats.

In most reported species, including human beings, cephalothin is rapidly and widely distributed into pleural, pericardial, peritoneal, and synovial fluids and most soft tissues. However, as happens with most beta-lactam antibiotics, its distribution is limited to the extracellular fluid with a volume of distribution in the range of $0.2-0.3 \mathrm{~L} / \mathrm{kg} .1,12 \mathrm{In}$ humans, cephalothin has a relatively high protein binding (around 50-60\%), 12 whereas, it is lower in horses (18\%) and dogs (20-46\%). $8,11,13$ Cephalothin is partially metabolized to desacetylcephalothin in the liver and, the parent drug and the metabolite are excreted through the kidneys by glomerular filtration and tubular secretion.2,12 Extension of metabolism varies with the species, being of $5-15 \%$ in humans, ${ }^{14}$ and greater in rabbits, dogs and horses. $5,9,11$ The antibacterial activity of desacetylcephalothin is only one-half to onesixteenth that of cephalothin, the lowest value corresponding to Bacillus subtilis ATCC $6633 .{ }^{15}$

Cephalothin plasma half-life elimination is lower than 1 hour in most studied species.8,11

Parenteral first generation cephalosporins are used, in human and veterinary medicine, mainly for prophylaxis of surgical wound infections. Also, parenteral first generation cephalosporins might be used to establish high tissue levels rapidly before using an oral cephalosporin. ${ }^{2}$ For surgical prophylaxis they should be administered intravenously around 30 minutes prior to the first tissue incision (to allow achieving therapeutic concentrations at tissue level when the incision is performed) only once. Administration can be repeated 90 minutes later in long lasting surgeries or when significant blood loss occurs. ${ }^{16}$

The aim of this study was to characterize the plasma pharmacokinetics and renal excretion of cephalothin, as well as, to determine its concentrations in selected tissues in cats under surgical conditions.
Correspondence: Gabriela A. Albarellos, Department of Pharmacology, Faculty of Veterinary Sciences, University of Buenos Aires, Av. Chorroarín 280, C1427CWO Buenos Aires, Argentina.

Tel.: +54.11.4524.8400.

E-mail: albarell@fvet.uba.ar

Key words: Antimicrobials; cephalosporins; pharmacokinetics; tissue concentrations; cats.

Contributions: the authors contributed equally.

Conflict of interest: the authors declare no potential conflict of interest.

Acknowledgments: the authors are indebted to Purina ProPlan, Argentina for the kind provision of the animal food.

Funding: this work was supported by a grant (Research Project UBACyT 20020100100745, 2011-2014 and UBACyT 20020130100400, 20142017) of Secretaría de Ciencia y Técnica, Universidad de Buenos Aires, Argentina.

Received for publication: 3 December 2014. Accepted for publication: 30 December 2014.

This work is licensed under a Creative Commons Attribution NonCommercial 3.0 License (CC BYNC 3.0).

(C) Copyright G. A. Albarellos et al., 2015

Licensee PAGEPress srl, Italy

Veterinary Science Development 2015; 5:5742

doi:10.4081/vsd.2015.5742

\section{Materials and Methods}

\section{Experimental animals}

Experimental animals were nine, 1 to 1.5 years old, mixed-breed cats (4 female and 5 males) with an average weight of $4.36 \pm 0.98$ $\mathrm{kg}$. All cats were healthy as determined by clinical examination, complete blood and serum biochemical analysis and urinalysis. Animals were housed in the Faculty of Veterinary Medicine, University of Buenos Aires facilities and allowed to acclimatize for two months before the experiment. Access to a high quality commercial dry food (Purina ProPlan ${ }^{\circledR}$, Buenos Aires, Argentina) and water was ad libitum. All animal procedures were approved by the Institutional Animal Care and Use Committee, School of Veterinary Science, University of Buenos Aires, Argentina.

\section{Dosage form}

An aqueous 10\% (cephalothin equivalent) w/v solution of cephalothin sodium salt (Keflin ${ }^{\circledR}$, Ivax, Buenos Aires, Argentina) was 
administered intravenously at a dose rate of 30 $\mathrm{mg} / \mathrm{kg}$. The dose was diluted in $3 \mathrm{~mL}$ of saline solution $(\mathrm{NaCl} 0.9 \%)$ before administration and injected through the cephalic vein over a 2 minute period.

\section{Experimental design}

Prior starting the study, two catheters (Jelco®, Smith Medical International Ltd., Milano, Italy) were placed into the cephalic veins. One of them (24G), was for antibiotic and fluid ( $\mathrm{NaCl} 0.9 \%, 10 \mathrm{~mL} / \mathrm{kg} / \mathrm{h})$ administration; and, the other (22G), for blood sample withdrawal.

Also, the urethra was catheterized to collect all urine produced during the complete duration of the study (6 hours).

Surgical procedures (ovariectomy or orchidectomy) were performed according to conventional standard techniques under general parenteral anesthesia (midazolam 0.2 $\mathrm{mg} / \mathrm{kg}$, ketamine $10 \mathrm{mg} / \mathrm{kg}$, xylazine 0.5 $\mathrm{mg} / \mathrm{kg}$ ). Cephalothin was administered intravenously 30 min prior first surgical incision.

\section{Blood sampling}

Blood samples $(0.7 \mathrm{~mL})$ were collected with a heparinized syringe at $0.08 ; 0.16 ; 0.33 ; 0.50$; $0.75 ; 1 ; 1.50 ; 2 ; 3 ; 4 ; 6$ hours after cephalothin administration.

Samples were centrifuged at $1500 \mathrm{rpm}$, for $15 \mathrm{~min}$, and then plasma was harvested and stored at $-20^{\circ} \mathrm{C}$ until analysis.

\section{Urine sampling}

Starting with an emptied urine bladder, all urine produced after cephalothin administration was collected at one hour intervals. The volume of each sample was recorded and an aliquot was stored at $-20^{\circ} \mathrm{C}$.

\section{Tissue sampling}

Tissue samples $(0.02-0.1 \mathrm{~g})$ were taken at 0.5-1 h after cephalothin administration. Selected tissues/organs were skin, subcutaneous, muscle, ovary, uterus, testicle and epididymis. Samples were rinsed briefly with saline solution and dried through gentle pressure with sterile gauze for removing blood contamination. Then, they were weighed and stored at $-20^{\circ} \mathrm{C}$.

Cephalothin was eluted from tissue samples following a technique described by Bamberg et al. ${ }^{17}$ Briefly, samples were cut into small pieces and diluted with phosphate buffer $\mathrm{pH} 6$ (in a ratio $1: 2 \mathrm{w} / \mathrm{v}$ ) and incubated for $24 \mathrm{~h}$ at $4^{\circ} \mathrm{C}$, applying agitation during the first $40 \mathrm{~min}$ of incubation. Finally, they were centrifuged (1500 rpm for $15 \mathrm{~min}$ ) and the supernatant harvested till assayed.

All collected samples (plasma, urine and tissue) were assayed within two weeks after collection.

\section{Cephalothin determination}

Cephalothin plasma, tissue and urine concentrations were determined by microbiological assay using Bacillus subtilis ATCC 6633 as test microorganism.18 Standard curves were prepared on normal cat plasma, phosphate buffer $\mathrm{pH} 6$ or normal cat urine, depending on the sample matrix to be quantified.

Each sample was seeded in triplicate and each standard dilution in quintuplicate.

Limit of detection and quantification of the method for the three assayed matrices was

Table 1. Pharmacokinetic parameters (mean \pm standard deviation) of cephalothin after intravenous administration to cats at a dose rate of $30 \mathrm{mg} / \mathrm{kg}(\mathrm{n}=9)$.

\begin{tabular}{lc}
\hline Pharmacokinetic parameter & Intravenous administration \\
$\mathrm{C}_{1}(\mu \mathrm{g} / \mathrm{mL})$ & $254.68 \pm 98.43$ \\
$\mathrm{C}_{2}(\mu \mathrm{g} / \mathrm{mL})$ & $99.11 \pm 42.09$ \\
\hline $\mathrm{C}_{\mathrm{p}(0)}(\mu \mathrm{g} / \mathrm{mL})$ & $353.79 \pm 118.92$ \\
$\lambda_{1(\mathrm{~h}-1)}$ & $8.03 \pm 5.63$ \\
\hline$\lambda_{2}(\mathrm{~h}-1)$ & $0.68 \pm 0.14$ \\
$\mathrm{AUC}_{(0-\mathrm{t})}(\mu \mathrm{g} . \mathrm{h} / \mathrm{mL})$ & $187.23 \pm 35.67$ \\
\hline $\mathrm{AUC}_{(0-\infty)}(\mu \mathrm{g} . \mathrm{h} / \mathrm{mL})$ & $189.69 \pm 36.66$ \\
$\mathrm{~K}_{12}(\mathrm{~h}-1)$ & $3.89 \pm 3.53$ \\
$\mathrm{~K}_{21}(\mathrm{~h}-1)$ & $2.96 \pm 2.17$ \\
$\mathrm{~T}_{1 / 2(\mathrm{~d})}(\mathrm{h})$ & $0.14 \pm 0.10$ \\
$\mathrm{~V}_{\text {area }}(\mathrm{L} / \mathrm{kg})$ & $0.23 \pm 0.05$ \\
$\mathrm{~V}_{(\mathrm{d}(\mathrm{s}))}(\mathrm{L} / \mathrm{kg})$ & $0.19 \pm 0.03$ \\
\hline $\mathrm{C}_{\mathrm{lB}}(\mathrm{L} / \mathrm{h} \cdot \mathrm{kg})$ & $0.16 \pm 0.03$ \\
$\mathrm{~T}_{1 / 2}(\mathrm{~h})$ & $1.07 \pm 0.23$ \\
\hline $\mathrm{MRT}(\mathrm{h})$ & $1.16 \pm 0.21$ \\
\hline
\end{tabular}

$\mathrm{C}_{1}, \mathrm{C}_{2}$ Y-axis intercept terms; $\mathrm{C}_{\mathrm{p}(0)}$ plasma concentration at 0 time; $\lambda_{1}$ distribution rate constant; $\lambda_{2}$ elimination rate constant; $\mathrm{AUC}_{(0-\mathrm{t})}$ area under the plasma concentration vs time curve from 0 to the last sampling time; $\mathrm{AUC}_{(0-\infty)}$ area under the plasma concentration vs time curve from 0 to infinite; $K_{12}$ rate constant for passage from central to peripheral compartment; $K_{21}$ rate constant for passage from peripheral to central compartment; Varea volume of distribution during the elimination phase; $\mathrm{V}_{(\mathrm{d}(\mathrm{ss}))}$ volume of distribution at steady state; $\mathrm{t}_{2 /(\mathrm{d})}$ distribution half life; $\mathrm{Cl}_{\mathrm{B}}$ body clearance; $\mathrm{t} \frac{1}{2}$ elimination half-life; MRT mean residence time.

Table 2. Cephalothin tissue concentrations (mean \pm standard deviation) taken between 30-60 min after cephalothin administration and, tissue/plasma concentration ratio after intravenous administration $(30 \mathrm{mg} / \mathrm{kg})$ to cats $(\mathrm{n}=9)$.

\begin{tabular}{lcc}
\hline Tissue (n) & Tissue concentration $(\mathrm{Hg} / \mathrm{g})$ & Tissue/plasma concentration ratio \\
Skin (9) & $15.85 \pm 5.44$ & $0.17 \pm 0.05$ \\
Subcutaneous (4) & $6.37 \pm 3.62$ & $0.06 \pm 0.03$ \\
\hline Muscle (4) & $6.46 \pm 1.85$ & $0.06 \pm 0.02$ \\
Ovary (8) & $18.24 \pm 4.38$ & $0.16 \pm 0.04$ \\
\hline Uterus (4) & $25.63 \pm 7.59$ & $0.21 \pm 0.05$ \\
Testicle (10) & $3.73 \pm 0.60$ & $0.04 \pm 0.01$ \\
\hline Epididymis (10) & $12.79 \pm 2.01$ & $0.15 \pm 0.04$ \\
\hline
\end{tabular}

Table 3. Cephalothin urinary elimination (cumulative percentage of the administered dose) after its intravenous administration to cats at a dose of $30 \mathrm{mg} / \mathrm{kg}(\mathrm{n}=9)$. Data are mean \pm standard deviation.

\begin{tabular}{cc}
$\begin{array}{c}\text { Time after cephalothin } \\
\text { administration (h) }\end{array}$ & $\begin{array}{c}\text { Cumulative percentage } \\
\text { of the administered dose in urine }\end{array}$ \\
$0-1$ & $34.16 \pm 6.57$ \\
$1-2$ & $51.65 \pm 12.91$ \\
\hline $2-3$ & $59.89 \pm 16.08$ \\
$3-4$ & $63.77 \pm 17.19$ \\
\hline $4-5$ & $65.75 \pm 17.85$ \\
$5-6$ & $66.49 \pm 17.71$ \\
\hline
\end{tabular}


$0.39 \mu \mathrm{g} / \mathrm{mL}$ and $0.78 \mu \mathrm{g} / \mathrm{mL}$. The method was linear between 0.39 and $200 \mu \mathrm{g} / \mathrm{mL}(\mathrm{r}=0.9955)$. Inter and intra-assay coefficients of variation were less than $10 \%$. Concentration results are expressed as cephalothin concentrations. However, since microbiological assay cannot distinguish between cephalothin and its sixteen times less active metabolite (acetylcephalothin), the reported cephalothin concentration actually represents cephalothin plus acetylcephalothin antimicrobial activity (cephalothin-like activity).

\section{Pharmacokinetic analysis}

Individual cephalothin plasma concentration $v s$. time curves were analysed by non-linear least square regression analysis using a computer software (Phoenix ${ }^{\circledR}$ WinNonlin ${ }^{\circledR}$ 6.3, 2005-2012, Certara, L.P., Princeton, USA).

Initial estimates were determined using the residual method and refitted by non linear regression. 19

The number of exponents needed for cephalothin intravenous administration data were determined by applying the Schwartz and Akaike criterions, ${ }^{20,21}$ and the residual distribution around the estimated concentrations.

Most pharmacokinetic parameters were calculated using classic equations associated with compartmental analysis. ${ }^{19}$

\section{Results}

Adverse effects were not observed during or following cephalothin intravenous administration in any of the cats.

Cephalothin plasma disposition curves in all the animals were best fitted to a biexponential model (Figure 1) according to an open bicompartmental model:

$$
C_{(t)}=Y_{1} \exp \left(-\lambda_{1} t\right)+Y_{2} \exp \left(\lambda_{2} t\right)
$$

where $\mathrm{C}_{(\mathrm{t})}(\mu \mathrm{g} / \mathrm{mL})$ represents cephalothin plasma concentration at $\mathrm{t}$ time; $\mathrm{Y}_{1}$ and $\mathrm{Y}_{2}$ $(\mathrm{mg} / \mathrm{mL})$ are the concentrations extrapolated to time 0 of the first and second phase of cephalothin plasma disposition and $\lambda_{1}$ and $\lambda_{2}$ (per $\mathrm{h}$ ) are the distribution and elimination slopes, respectively. The average equation for the model was:

$$
C p=254.68 \mathrm{e}^{-8.03}+99.11 \mathrm{e}^{-0.68 \mathrm{t}}
$$

Main pharmacokinetic parameters (mean \pm standard deviation) are reported in Table 1.

Cephalothlin showed a fast distribution, reflected by the rate constant of the process $\left(\lambda_{1} 8.03 \pm 5.63 \mathrm{~h}^{-1}\right)$ and its short half-life $\left(\mathrm{T}_{1 / 2(\mathrm{~d})}\right.$ $0.14 \pm 0.10 \mathrm{~h})$. The extent of distribution was moderate $\left(\mathrm{V}_{(\mathrm{d}(\mathrm{ss}))} 0.19 \pm 0.03 \mathrm{~L} / \mathrm{kg}\right)$.

Cephalothin was rapidly eliminated from the body with a total body clearance $\left(\mathrm{Cl}_{\mathrm{B}}\right)$ of $0.16 \pm 0.03 \mathrm{~L} / \mathrm{h} . \mathrm{kg}$, an elimination half-life $\left(\mathrm{T}_{1 / 2}\right)$ of $1.07 \pm 0.23 \mathrm{~h}$ and a mean residence time (MRT) of $1.16 \pm 0.21 \mathrm{~h}$.

Cephalothin tissue concentrations and tissue/plasma concentrations rates are shown in Table 2. Tissue concentrations were always lower than the corresponding plasma concentrations. The highest concentrations were found in uterus, ovary and skin, while, the lowest were found in testicle, subcutaneous and muscle.

Cephalothin was rapidly and extensively eliminated in urine $(66.49 \%$ of total the administered dose in a 6 hour period). The cumulative percentage excreted in urine throughout the study is shown in Table 3 . Cephalothin urine concentrations were very high at all sampling times, with a peak value of $5438.04 \pm 3545.27 \mu \mathrm{g} / \mathrm{mL}$ during the first hour and, a minimum of $145.01 \pm 183.93 \mu \mathrm{g} / \mathrm{mL}$ during the sixth hour.

\section{Discussion}

Cephalothin, as a representative member of the parenteral first generation cephalosporins, shares with the group the same clinical use indications. That is the intravenous treatment of soft tissue infections where a bacterial susceptibility test points a first generation cephalosporin. Also, as same as cefazolin, it is a good choice to prevent surgical site infections in clean-contaminated wounds.

For these purposes and tending to a rational usage, antibiotic pharmacokinetic features and tissue concentrations should ideally be characterized. The present study can bring useful information since it describes cephalothin plasma pharmacokinetics, tissue concentrations, and urine elimination after its intravenous administration to cats.

The study was conducted on anaesthetized cats and, the authors are aware that under this circumstances, the calculated pharmacokinetic parameters could result altered. However, we preferred choosing experimental conditions those that simulated actual surgical settings.

A weakness of the present study is that samples taken from tissues correspond to a unique time point after cephalothin administration. However, the sampling time was chosen taking into consideration surgical timing when highest antibiotic concentrations in tissues are required.

Cephalothin concentrations in all the studied matrices were determined through the microbiological assay.18 This method was extensively used to determine cephalothin concentrations in many studies.7-14,22,23 However, because the microbiological assay does not discriminate between the active drug (cephalothin) and its active metabolite (acetylcephalothin), it is criticized for some authors. Nevertheless, we have selected it because of its sensibility, simplicity and good correlation with HPLC determination. ${ }^{9}$

Plasma cephalothin disposition curves after intravenous administration were best fitted by an open bicompartmental model in all the cats. This is in agreement with human and horses pharmacokinetic studies.11,14

After cephalothin administration, initial plasma extrapolated concentrations were very high $\left(\mathrm{C}_{\mathrm{p}(0)} 353.79 \mu \mathrm{g} / \mathrm{mL}\right)$, and declined rapidly

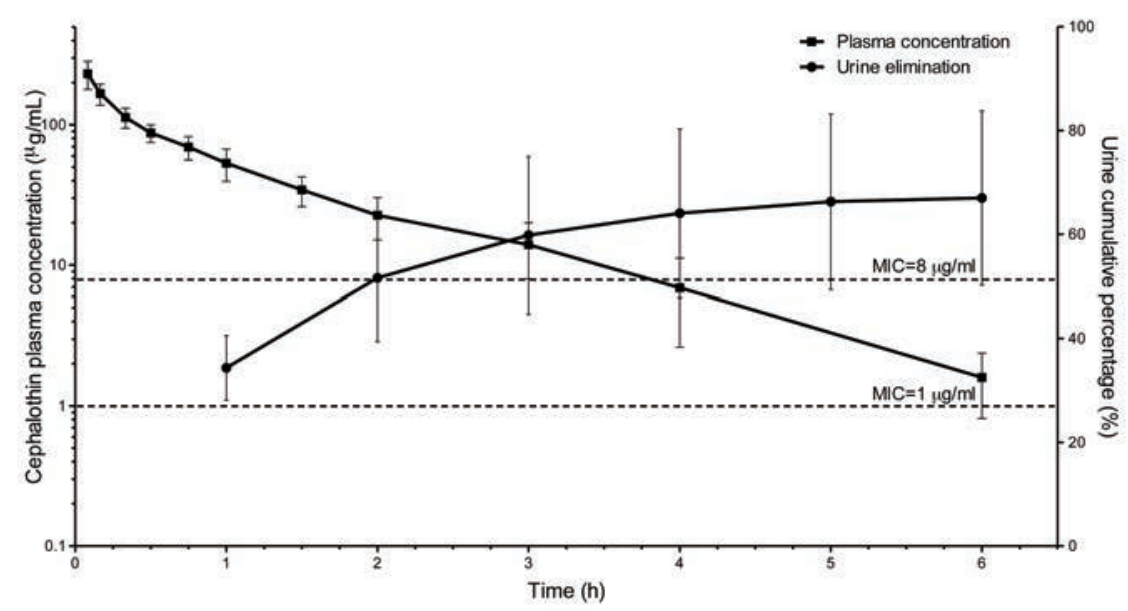

Figure 1. Mean ( \pm standard deviation) cephalothin plasma concentration-time profile ( $(-)$ and cumulative urine elimination $(\bullet)$ after intravenous administration to cats $(n=9)$ at a dose of $30 \mathrm{mg} / \mathrm{kg}$. Minimum inhibitory concentration (MIC) values correspond to Staphylococcus spp $(\mathrm{MIC} 90=1 \mu \mathrm{g} / \mathrm{mL}$ ) and MIC breakpoint for veterinary pathogens (MIC $\leq 8 \mu \mathrm{g} / \mathrm{mL})$. 
(as it is shown through the distribution and elimination rate constants: $\lambda_{1}, 8.03 \mathrm{~h}^{-1}$ and $\lambda_{2}$, $0.68 \mathrm{~h}^{-1}$ ). Cephalothin plasma concentrations were still detectable ( $>1 \mu \mathrm{g} / \mathrm{mL}$ in $7 / 9$ animals) up to the last sampling time $(6 \mathrm{~h})$.

In general terms, plasma pharmacokinetic profile of cephalothin in cats is the predicted for a beta-lactam antibiotic, being similar to that reported by other authors in other species.5,9-11,13,14,23

Cephalothin in cats, as expected for a watersoluble beta-lactam, seems to be distributed exclusively into extracellular fluids, as reflected by the low $\mathrm{V}_{(\mathrm{d}(\mathrm{ss}))}(0.19 \mathrm{~L} / \mathrm{kg})$. However, mean cephalothin tissue concentration after $\approx 1 \mathrm{~h}$ administration was above $1 \mu \mathrm{g} / \mathrm{mL}$ ( $\mathrm{MIC}_{90}$ for Staphylococcus and Streptococcus species). ${ }^{2}$ In a previous study performed on mice, rats, rabbits and dogs, similar high cephalothin tissue concentrations (in lung, liver, spleen and kidney) were reported. ${ }^{7}$ Cephalothin concentrations found in tissues of cats are high enough to prevent bacteria colonization of soft tissues during common surgical procedures.

In the present study, differences were found between tissues in the rate of cephalothin penetration and, also in the tissue/plasma concentration ratio. These differences are probably due to anatomical and physiological particularities of each sampled organ. Tissue/plasma rates are in accordance to the magnitude of cephalothin tissue concentration, corroborating that cephalothin penetrates into some tissues (e.g. uterus) better than in others (e.g. testicle).

Estimated tissue/plasma ratios for all tissues were always less than unity, confirming that the distribution of cephalothin is restricted to the vascular and extracellular fluid.

In human beings, cephalothin is eliminated mainly active (65\%) through the kidneys by tubular secretion and glomerular filtration reaching very high urine concentrations. ${ }^{12}$ In our study cephalothin (as total antibacterial activity) was found in urine in quantities as high as $5438.04 \mu \mathrm{g} / \mathrm{mL}$ and $145.01 \mu \mathrm{g} / \mathrm{mL}$ (during the first and the last hour sampled, respectively). It seems that cephalothin and its active metabolite were eliminated faster in cats ( $66.49 \%$ of the administered dose in $6 \mathrm{~h}$ ) than in men $(66 \%$ in $24 \mathrm{~h}){ }^{23}$

To predict the theoretical efficacy of cephalotin in the prophylaxis of surgical infections, plasma concentrations of cephalothin could be compared to MIC values for pathogenic bacteria that could colonize wounds. When considering a $\mathrm{MIC}_{90}$ for Staphylococcus spp. of $1 \mu \mathrm{g} / \mathrm{mL}^{2}$ cephalothin plasma concentrations remain above this value for $\approx 5.50$ hours. However, if MIC breakpoint for susceptible bacteria $(\leq 8 \mu \mathrm{g} / \mathrm{mL})^{3}$ is considered, cephalothin would be effective for only $\approx 2.5$ hours. So, depending on the expected contamination source and the length of the surgery, it would be advisable to repeat the administration 2 hours after the first dose.

\section{References}

1. Papich MG, Riviere JE. -lactam antibiotics: penicillins, cephalosporins, and related drugs. In: Riviere JE, Papich MG, eds. Veterinary pharmacology and therapeutics. 9th ed. Ames: Wiley-Blackwell; 2009. pp 865-893.

2. Prescott JF. Beta-lactam antibiotics: cephalosporins. In: Giguère $S$, Prescott JF, Dowling PM, eds. Antimicrobial therapy in veterinary medicine. 5th ed. Ames: Wiley Blackwell; 2013. pp 153-173.

3. Clinical and Laboratory Standards Institute. Performance standards for antimicrobial disk and dilution susceptibility test for bacteria isolated from animals. Second informational supplement CLSI document VET01-S2. Wayne (PA), USA; 2013.

4. Turnidge JD. The pharmacodynamics of Lactams. J Clin Infect Dis 1998;27:10-22.

5. Bergeron MG, Nguyen BM, Trottier S, Gauvreau L. Penetration of cefamandole, cephalothin and desacetylcephalothin into fibrin clots. Antimicrob Agents Chemother 1977;12:682-7.

6. Fabre J, Blanchard P, Rudhardt M. Pharmacokinetics of ampicillin, cephalothin and doxycycline in various tissues of the rat. Chemother 1977;23:129-41.

7. Tsuchiya K, Kondo M, Kita Y, et al. Absorption, distribution and excretion of SCE-963, a new broad-spectrum cephalosporin, in mice, rats, rabbits and dogs. J Antibiot 1978;31:1272-82.

8. Gerdin DN, Peterson LR, Legler DC, et al. Ascitic fluid cephalosporin concentrations: influence of protein binding and serum pharmacokinetics. Antimicrob Agents Chemother 1978;14:234-9.

9. Nilsson-Ehle I, Yoshikawa TT, Schotz MC, Guze LB. Quantitation of antibiotics by high-pressure liquid chromatography: cephalothin. Antimicrob Agents Chemother 1978;13:221-7.

10. Petersen SW, Rosin E. Cephalothin and cefazolin in vitro antibacterial activity and pharmacokinetics in dogs. Vet Surg 1995;24:347-51.

11. Ruoff WW, Sams RA. Pharmacokinetics and bioavailability of cephalothin in horse mares. Am J Vet Res 1985;46:2085-90.

12. Roberts JA, Lipman J, Paterson DL. Cephalothin and cefazolin. In: Grayson LM, ed. Kucers' The use of antibiotics, 6th ed. Boca Raton: CRC Press; 2010. pp 25767.

13. Studley JGN, Schentag JJ, Schenk WG, Jr. Excretion of cephalothin and cefamandole by the normal pancreas and in acute pancreatitis in dos. Antimicrob Agents Chemother 1982;22:262-5.

14. Barza M, Melethil S, Berger S, Ernst C. Comparative pharmacokinetics of cefamandole, cephapirin and cephalothin in healthy subjects and effect of repeated dosing. Antimicrob Agents Chemother 1976;10:421-5.

15. Wick, WP. In vitro and in vivo laboratory comparison of cephalothin and desacetylcephalothin. Antimicrob Agents Chemother 1965;5:870-5.

16. Fossum TW. Small animal surgery. 4th ed. St. Louis: Elsevier Mosby; 2013. pp 89-94.

17. Bamberger DM, Foxworth JW, Bridwell DL, et al. Extravascular antimicrobial distribution and the respective blood and urine concentrations in humans. In: Lorian V, ed. Antibiotics in laboratory medicine, 5 th ed. Philadelphia: Lippincott Williams \& Wilkins; 2005. pp 719-814.

18. Bennet JV, Brodie JL, Bennet EJ, Kirby WM. Simplified accurate method for antibiotic assay of clinical specimens. Appl Microbiol 1966;14:170-7.

19. Gibaldi M, Perrier D. Pharmacokinetics. 2nd ed. New York: Marcel Dekker Inc.; 1982.

20. Schwartz G. Estimating the dimension of a model. Ann Stat. 1978;6:461-4.

21. Yamaoka K, Nakagawa T, Uno T. Application of Akaike's information criterion (AIC) in the evaluation of linear pharmacokinetic equations. J Pharmacokinet Biopharm 1978;6:165-75.

22. Rattie ES, Ravin LJ. Pharmacokinetic interpretation of blood levels and urinary excretion data for cefazolin and cephalothin after intravenous and intramuscular administration in humans. Antimicrob Agents Chemother 1975;7:606-13.

23. Fong IW, Ralph ED, Engelking ER, Kirby WMM. Clinical pharmacology of cefamandole as compared with cephalothin. Antimicrob Agents Chemother 1976;9:659. 